Article

\title{
Examining the Impact of Innovation Forms on Sustainable Economic Performance: The Influence of Family Management
}

\author{
Rubén Martínez-Alonso *(D), María J. Martínez-Romero® and Alfonso A. Rojo-Ramírez $₫$ \\ Faculty of Economics and Business, Universidad de Almería, 04120 Almería, Spain; \\ mariaj.martinez@ual.es (M.J.M.-R.); arojo@ual.es (A.A.R.-R.) \\ * Correspondence: ruben.martinez@ual.es
}

Received: 15 October 2019; Accepted: 30 October 2019; Published: 3 November 2019

\begin{abstract}
The aim of this research is to explore the effect that innovation, as a potential source of sustained competitive advantage and firm growth, has on the achievement of sustainable economic performance. In particular, this paper empirically examines the influence of four innovation forms (intramural R\&D, extramural R\&D, product innovation, and process innovation) on firms' sustainable economic performance, considering the moderating effect of family involvement in management. To test the hypotheses, random-effects regression analyses are applied to a longitudinal sample of 598 Spanish private manufacturing firms throughout the 2006-2015 period. The results show a negative effect of intramural and extramural R\&D on sustainable economic performance and a positive effect of process innovation on sustainable economic performance. Moreover, a reinforced relationship between process innovation and sustainable economic performance is also revealed when family involvement in management acts as a moderator. The findings make several contributions to research and practice.
\end{abstract}

Keywords: sustainable economic performance; innovation; intramural R\&D; extramural R\&D; product innovation; process innovation; family involvement in management

\section{Introduction}

The pursuit of sustainable performance is widely regarded as a central idea in the business world [1], to the extent that striking a balance between sustainability and economic development has become a key objective for many firms [2,3]. This is because, through a more sustainable behavior, firms are able to obtain social and environmental benefits, maintain their competitiveness in the long-term, and achieve better levels of profitability [4]. In view of the foregoing, a growing number of firms are incorporating sustainable development initiatives into their corporate strategies, policies and culture to improve firm performance and to strengthen the long-term interests of the business, stakeholders and society [4]. Thus, in the business context, sustainable performance is a construct that embraces economic, social, and environmental aspects $[5,6]$. The present study addresses the economic facet of sustainable performance, because determining whether firms that are more resilient in economic terms can endure over time, remains a major challenge in the literature $[7,8]$.

Sustainable economic performance, also known as long-term performance, involves, among other issues, preserving and expanding economic growth, creating shareholder value, fostering customer relationships or improving the quality of products and services [4]. Nevertheless, the measurement of sustainable economic performance is a very difficult and sophisticated task [6], since firm performance is a multidimensional concept encompassing a complex diversity of performance indicators that are not necessarily related $[9,10]$ and might lead to diverse results $[10,11]$. Thus, this study is focused on one of 
the classical dimensions of performance, i.e., profitability, operationalized through the return on asset ratio (ROA), which is considered an appropriate financial indicator of sustainable performance [4].

On the other hand, some researchers [4] also point out that sustainable economic performance is contingent upon a set of managerial (e.g., risk management), operational (e.g., reduction of inputs) or economic (e.g., innovation) factors, that is, variables that contribute to the achievement of firms' long-term performance. Concretely, innovation has been identified as one of the most valuable sources of sustainable competitive advantages [12,13], enabling firms to grow and evolve even faster, survive and endure over time in rapidly changing environments, be more efficient in managing firm resources and ultimately, achieve superior performance outcomes [10,14]. However, innovation also constitutes a multifaceted phenomenon and therefore, its influence on long-term performance cannot be evaluated as a sole variable $[15,16]$. Thereby, it is analyzed how different innovation forms, i.e., intramural $R \& D$, extramural $R \& D$, product innovation, and process innovation, encompassing both innovation inputs and outputs, impact on sustainable economic performance. Even though some efforts have been made in prior studies to understand how innovation, and specifically, different innovation forms, such as information technology, organizational, or marketing innovations, impact on sustainable economic performance $[5,12,17]$, the results obtained up to now are scarce and far from being conclusive. Moreover, there is also a lack of studies examining specific factors that may moderate the relationship between innovation forms and long-term performance. Therefore, in a further attempt to delve into such links, this article introduces family involvement in management as a firm strategic factor, which may improve the influence of alternative innovation forms on sustainable economic performance.

In view of the preceding considerations and to shed some light on these under-researched issues, this article addresses the following research questions: Does innovation, through its different forms, influence sustainable economic performance? Does family involvement in management moderate the expected relationships between innovation forms and sustainable economic performance? To answer both questions, random-effects regression analyses are performed on a longitudinal sample of 598 Spanish private manufacturing firms using unbalanced panel data.

This paper offers relevant contributions. This is one of the pioneering studies analyzing the impact of different innovation forms on sustainable economic performance in a private manufacturing firm context. This paper also reveals a positive moderating effect of family involvement in management on the relationship between process innovation and long-term performance, leading to greater firms' sustainable economic performance. To the best of the authors' knowledge, no previous study examining the above links had used family management as a moderator. In this regard, this study answers the call for more research on how and why innovation impact on sustainable economic performance $[3,18]$ and also the call to explore when and to what extent family involvement in management influences innovation-related decisions and activities to achieve long-term performance $[19,20]$.

Following this introductory section, Section 2 examines the main theoretical aspects of the relationship between innovation forms and sustainable economic performance, as well as the role of family involvement in management in this link. Then, the research methodology and the result analysis are presented in Sections 3 and 4, respectively. Section 5 introduces the discussion. Section 6 includes the contributions, limitations and future research lines, and some practical implications. Finally, Section 7 provides the concluding remarks.

\section{Theoretical Foundations and Hypotheses Development}

\subsection{Innovation Forms and Sustainable Economic Performance}

Since Schumpeter outlined the significant role of innovation in the development of economies worldwide in 1934, innovation has been widely recognized as a key factor in strengthening sustained competitive advantages and ensuring the survival and prosperity of firms in an increasingly changing environment $[3,18,21]$. Its impact on the achievement of sustainable economic performance is 
of enormous importance [4,22], as several researchers have largely shown that firms implementing innovations are more likely to grow and endure over time than their non-innovative counterparts $[23,24]$.

Prior studies have pointed out that innovation often exerts a positive effect on firms' long-term performance and that such an effect may vary depending on the applied innovation form [24,25]. Generally speaking, innovation is a complex process and a multidimensional phenomenon and thus, its effect on sustainable economic performance cannot be assessed as a single construct $[15,16]$. Many innovative firms, being aware of this fact, make the most of themselves to improve their performance outcomes through the execution of different innovation practices. Among the different innovation forms analyzed in prior innovation-performance studies, the literature highlights certain innovation inputs, such as intramural R\&D [26] and extramural R\&D [27], as well as some innovation outputs, such as product innovations [28] and process innovations [29]. Nevertheless, the research on innovation has so far failed to conclusively demonstrate whether particular innovation forms have a higher impact on sustainable economic performance than others.

Therefore, based on the preceding ideas, it seems highly necessary to obtain a richer understanding of the effect that each of the abovementioned innovation forms has on firms' sustainable economic performance.

\subsubsection{Innovation Inputs}

$R \& D$ is a key innovation input that contributes to firms' productivity and to their long-term performance [30,31]. R\&D brings several benefits to firms, such as the required expertise for obtaining successful innovations (e.g., process innovation), which has the potential to strengthen the competitiveness of organizations and industries [32], expanding the likelihood of substantial discoveries [27].

Firms often carry out both intramural and extramural R\&D to optimize the ability to increase their long-term profits [33]. Intramural R\&D refers to "the creative work undertaken on a systematic basis within the enterprise in order to increase the stock of knowledge and use it to devise new applications" [34] (p. 97). This embraces all R\&D performed by the firm, including basic research. The importance of intramural $R \& D$ as an engine of innovations is unquestionable [28,35], since it enables more fluid communication between the different departments involved, creates firm-specific knowledge and generates absorptive capacity, which favors greater economies of scale and minimizes transaction costs [36-38]. However, these beneficial effects can be counterbalanced by less predictable and riskier outcomes, as well as by a higher probability of remaining isolated in a particular technological development $[39,40]$.

Extramural R\&D applies to "the same activities as intramural R\&D but purchased from public or private research organizations or from other enterprises (including other enterprises within the group" [34] (p. 97). Similarly to intramural R\&D, the activities linked to extramural R\&D can improve firms' efficiency, innovation capabilities and knowledge resources [41,42], also encouraging firm growth and performance over time [27]. Extramural R\&D provides firms the opportunity to minimize the risk associated with such investments through its a priori calculation, increases the speed of access to new knowledge and gives solutions to capacity problems [43]. Nevertheless, these activities also entail increased transaction costs, the emergence of opportunistic behaviors by R\&D partners, and other problems of external dependence, functional disparities, and coordination with them, which could jeopardize the firms' capacity to conduct innovations, and thus, reduce its impact on long-term performance $[37,44]$.

Although it is challenging to predict the effect (positive or negative) that both intramural and extramural R\&D will have on sustainable economic performance because of the existence of both detrimental and favorable arguments, previous research suggests that these forms of innovation inputs will have a significant effect on firm performance $[45,46]$. Namely, innovation investments are developed with the final goal of achieving innovation outputs, and thus increasing economic outcomes. However, when intramural and extramural R\&D expenses are carried out, the firms' potential operating 
result will be reduced $[47,48]$, and thus the economic performance will be also diminished $[49,50]$. That is, as R\&D expenses increase, the lower will be the firm profitability. Stated formally:

Hypothesis 1 (H1): Intramural R\&D expenses exert a negative impact on sustainable economic performance

Hypothesis 2 (H2): Extramural R\&D expenses exert a negative impact on sustainable economic performance

\subsubsection{Innovation Outputs}

Innovation outputs are increasingly becoming crucial sources for firms' long-term performance and competitiveness [28,51]. In this respect, prior studies have revealed a clearer direct positive effect of innovation outputs on performance indicators than that displayed in the case of innovation inputs $[32,52,53]$.

Particularly, the ability of firms to effectively compete in markets and experience continuous growth over time is conditioned by the extent to which they develop product and process innovations $[51,54]$. Product innovation consists of "the introduction of a good or service that is new or significantly improved with respect to its characteristics or intended uses" [34] (p. 48). Product innovations comprise substantial changes in the capabilities, that is, technical specifications, components, and materials or embedded software, of goods or services. In fact, product innovations have become important tools to sustain competitive advantages in the market [55], inasmuch as product innovations allow firms to improve and maintain their market position over time, establish a positive image and reputation through the brand name, better acknowledge customers' needs and requirements, and also increase customers' demand and profits margins [56,57]. Moreover, by means of the development of product innovations, firms are able to compete more successfully than their competitors by gaining first-mover advantages, and thus, by increasing their sales volumes and overall business success $[58,59]$. However, product innovations also often present certain difficulties as a result of changing customer needs, shortening product life cycles and growing global competition [60,61].

On the other hand, process innovation refers to "the implementation of a new or significantly improved production or delivery method" [34] (p. 49). This involves major technical, equipment, and/or software changes. Unlike product innovation, which is market- and customer-oriented, process innovation has a more internal focus and aims to enhance firm efficiency, quality, and also to reduce production costs or delivery processes $[29,62]$. In this regard, firms that implement process innovations obtain greater cost savings resulting in cost advantages over their competitors and in the possibility of making some tangible benefits [21,54]. Moreover, this innovation form makes it possible to optimize the allocation of capital and increase labor productivity [63,64], enabling greater profit margins at the prevailing market price, thus, facilitating the achievement of superior long-term performance [34]. Nonetheless, some authors have also stated that the benefits derived from process innovation could be apparent in later stages due to their dependence on certain complementary assets that are not always available and its cost-cutting nature $[27,61]$.

Accordingly, considering the abovementioned arguments, it is expected that innovation outputs will increase firms' potential operating results [19,32], due to the higher incomes arising from greater sales volume, internal efficiency, and market competitiveness, thereby increasing long-term performance. Hence, as innovation outputs increase, the higher will be the firm profitability. Stated formally:

Hypothesis 3 (H3): Product innovation exerts a positive impact on sustainable economic performance

Hypothesis 4 (H4): Process innovation exerts a positive impact on sustainable economic performance 


\subsection{The Influence of Family Involvement in Management}

Family firms are important and prevalent types of firms in all economies worldwide $[65,66]$, which are widely characterized by prioritizing non-economic and social goals over economic objectives $[67,68]$. Besides, family firms are recognized because of their distinctive decision-making processes, due to the overlap between the family unit and the business entity [69]. In this vein, many studies indicate that family firms present a special linkage between their management, ownership and governance structures [70,71] that favors the development of specific family firm resources and the entrenchment of sustainable competitive advantages, making them appealing organizational forms for analyzing innovation and firm performance phenomena [20,72]. Particularly, the family presence in the firm management strengthens the unique set of family goals and enables family members to effectively engage in the execution of businesses' decisions, strategies and activities [73,74], which influences how different innovation forms are managed and implemented [10,54], and therefore, the singular way in which family members manage their firms may have a significant impact on the achievement of long-term performance [19].

Previous studies [75] agree that family firms, and specifically family-managed firms, present a set of idiosyncratic characteristics, such as long-term orientation [76], tacit knowledge [77], social capital [78] and outstanding commitment to firm survival [74], which encourage innovation practices and thus, long-term performance [20]. These features are more pronounced as the integration among family and business becomes stronger [69,75]. Namely, family-managed firms are endowed with a superior tacit knowledge [54,79], which is generated through the singular, deep and long-term family managers' interactions with employees and other stakeholders. Furthermore, the transmission of tacit knowledge through the firms' members, departments and networks is an important source of sustainable competitive advantages for innovation, and therefore, for long-term performance [77,80]. On the other hand, family-managed firms may also possess greater social capital, which promotes the cultivation, nurturing and development of quality and long-term relationships across generations with internal and external stakeholders [81] and makes it possible to identify and actively develop continued innovation opportunities over time [82]. Moreover, family-managed firms are also distinguished by their long-term orientation and their extraordinary commitment to firm survival [28], which also contributes to more effective development of different innovation forms and thus, boots sustainable economic performance.

In short, family-managed firms will take full advantage of their idiosyncratic characteristics for innovation (e.g., tacit knowledge) with the ultimate goal of achieving long-term performance. Specifically, family involvement in management may strengthen sustainable economic performance by weakening the negative effect of intramural and extramural R\&D on the generated performance, and by reinforcing the positive effect of product and process innovations on long-term performance, leading in all instances to superior economic performance. Hence, family involvement in management is argued to act as a moderator of the relationship between innovation forms and sustainable economic performance. Stated formally:

Hypothesis 5: Family involvement in management moderates the relationships between innovation forms and sustainable economic performance. Particularly, family management weakens the negative relationships between (H5a) intramural R\&D, and (H5b) extramural R\&D and sustainable economic performance, whereas, family management strengthens the positive relationships between $(\mathrm{H} 5 \mathrm{c})$ product innovation, and $(\mathbf{H} 5 \mathrm{~d})$ process innovation and sustainable economic performance.

Figure 1 shows the theoretical model and the proposed hypotheses. 


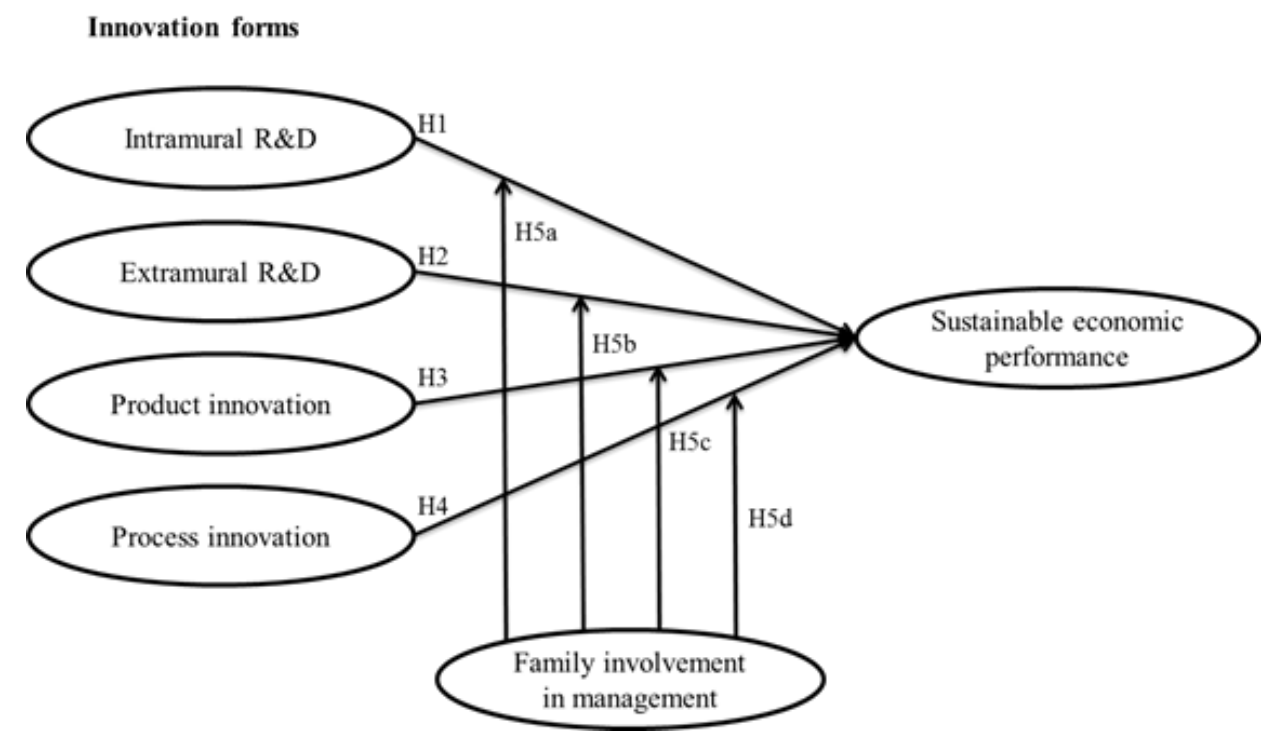

Figure 1. Theoretical model and hypotheses.

\section{Research Methodology}

\subsection{Sample}

The sample used comprises an unbalanced panel of 598 Spanish private manufacturing firms in the 2005-2016 period, resulting in 5,304 firm-year observations. The data come from the Survey on Business Strategies (ESEE), which is annually conducted by the SEPI Foundation in collaboration with the Spanish Ministry of Industry since 1990. The ESEE is specifically designed to collect data from Spanish private manufacturing firms. The survey includes an average of 1,800 firms per year and contains a wide range of information related to their innovation strategies and economic outcomes, among other issues. As years progress, certain firms leave the sample and are substituted by other firms of similar size, which belong to the same industry. Furthermore, the quality of the data is ensured by the data collection process, to the extent that response rates oscillate between $81 \%$ and $95 \%$ approximately and involve the participation of multiple organizational members (in each company, the survey is completed by an average of 2.5 people). Therefore, the ESEE sampling procedure guarantees the representativeness of the population.

Additionally, the choice of the manufacturing industry is especially appropriate for the purpose of this study, as the high degree of obsolescence that these firms often experience in their products leads them to rely on innovation in order to conserve their degree of competitiveness in the long-term $[10,83]$. In fact, this data source is very reliable, and its utilization in prior innovation, performance, and family firm studies in the Spanish landscape corroborates it $[28,79,84]$.

A more detailed view of the sampled firms' characteristics for the year 2016 is given in Table 1. In short, just over $50 \%$ are family-managed firms, small- and medium-size firms predominate over large-size firms, and most of the sampled firms are located in the east (37.63\%) and the center $(18.23 \%)$ of Spain. Finally, with respect to industries, most businesses develop their activity in metal products (14.21\%) and foodstuffs and snuff (11.87\%) subindustries. 
Table 1. Sample characteristics (2016).

\begin{tabular}{|c|c|c|}
\hline \multicolumn{3}{|c|}{ Sample composition by size ${ }^{a}$ and family/non-family management } \\
\hline & $\mathrm{N}$ & $\%$ \\
\hline Family-managed firms & 301 & 50.33 \\
\hline Non-family-managed firms & 297 & 49.67 \\
\hline Total & 598 & 100.00 \\
\hline Large-size firms & 177 & 29.60 \\
\hline Medium-size firms & 127 & 21.24 \\
\hline Small-size firms & 294 & 49.16 \\
\hline Total & 598 & 100.00 \\
\hline \multicolumn{3}{|c|}{ Sample composition by territorial subdivisions ${ }^{b}$} \\
\hline & $\mathrm{N}$ & $\%$ \\
\hline 1. Northwest & 73 & 12.21 \\
\hline 2. Northeastern & 78 & 13.04 \\
\hline 3. Madrid & 37 & 6.19 \\
\hline 4. Center & 109 & 18.23 \\
\hline 5. East & 225 & 37.63 \\
\hline 6. South & 55 & 9.20 \\
\hline 7. Canarias & 21 & 3.51 \\
\hline Total & 598 & 100.00 \\
\hline \multicolumn{3}{|c|}{ Sample composition by subindustry ${ }^{c}$} \\
\hline & $\mathrm{N}$ & $\%$ \\
\hline 1. Meat industry & 21 & 3.51 \\
\hline 2. Foodstuffs and snuff & 71 & 11.87 \\
\hline 3. Drinks & 22 & 3.68 \\
\hline 4. Textiles and clothing & 39 & 6.52 \\
\hline 5. Leather and footwear & 16 & 2.68 \\
\hline 6. Timber industry & 17 & 2.84 \\
\hline 7. Paper Industry & 25 & 4.18 \\
\hline 8. Graphics & 22 & 3.68 \\
\hline 9. Chemical and pharmaceutical products & 45 & 7.53 \\
\hline 10. Rubber and plastic & 37 & 6.19 \\
\hline 11. Non-metallic mineral products & 25 & 4.18 \\
\hline 12. Ferrous and non-ferrous metals & 20 & 3.34 \\
\hline 13. Metal products & 85 & 14.21 \\
\hline 14. Agricultural and industrial machinery & 38 & 6.35 \\
\hline 15. Computer, electronic and optical products & 11 & 1.84 \\
\hline 16. Electrical machinery and material & 26 & 4.35 \\
\hline 17. Motor vehicles & 34 & 5.69 \\
\hline 18. Other transport equipment & 13 & 2.17 \\
\hline 19. Furniture industry & 19 & 3.18 \\
\hline 20. Other manufacturing & 12 & 2.01 \\
\hline Total & 598 & 100.00 \\
\hline
\end{tabular}

a Small, medium, and large firms have been classified based on the European Commission criteria (2003/361/CE, 6th May). ${ }^{\mathrm{b}}$ NUTS1 (Nomenclature des Unités Territoriales Statistiques). ${ }^{\mathrm{c}}$ The ESEE divides the manufacturing industry into 20 subindustries.

\subsection{Measurement Variables}

\subsubsection{Dependent Variable}

Prior studies have emphasized that an adequate measure of sustainable economic performance is that capturing the continued growth of firms' economic performance during a determined number of years [4]. In this study, economic performance is calculated as ROA (earnings before interest and tax to total assets), which is well accepted by the Global Reporting Initiative (GRI) as a financial measure of sustainable performance [4]. Therefore, following the abovementioned arguments and similarly 
to Cho and Pucik [85], and Diéguez-Soto et al. [19], the dependent variable is calculated as the mean ROA in a four-year period ( $t-3, t-2, t-1$, and $t)$.

\subsubsection{Independent Variables}

As previously argued, a distinction is made between four innovation forms, in order to investigate the specific effect that different innovation practices exert on sustainable economic performance, discriminating in this way between innovation inputs and outputs. Thus, intramural R\&D intensity, extramural R\&D intensity, product innovation, and process innovation are established as the independent variables of the present study.

Intramural R\&D intensity is measured as the ratio between intramural R\&D expenditures and total sales [86]. Intramural R\&D intensity has been utilized as a proxy of absorptive capacity [83], inasmuch as sourcing resolutions are commonly affected by the firms' capacity to incorporate novel capabilities [36].

Extramural R\&D intensity is measured as the ratio of extramural $R \& D$ expenditures to total sales [35]. This measurement is thus, focused on R\&D contracting, capturing the expenses that firms carry out to buy R\&D services from different organizations, such as for example, suppliers, competitors, universities, and public research organizations [87].

Both measures of innovation inputs are three year lagged [32,88] due to the purpose of this study and because of the nature of the dependent variable, which is calculated using lagged averaged performance data during the past three years. These lags aim to determine whether R\&D investments have a temporary effect on sustainable economic performance [39]. In this regard, it is widely acknowledged that both intramural and extramural R\&D strategies usually constitute long-term processes whose performance outcomes are obtained in later years after their implementation [28].

Product innovation occurs when firms introduce entirely new products, or products with significant modifications, novel functions or variations in their presentations, components, designs, or compositions. Product innovation is measured through a dummy variable that captures whether or not a firm introduced innovations in product functionalities, and/or design [28]. Prior research has also used dichotomous variables as measures of innovation output when firms innovate in terms of product $[21,89]$.

Process innovation takes place when firms implement new or significantly improved production or delivery methods [34]. Process innovation is measured with a dummy variable that establishes whether or not a firm has introduced new or significant modifications in their production processes mainly by the placement of new equipment, machinery, methods, and/or techniques [27]. As in the case of product innovations, previous studies have employed dichotomous variables to account for process innovations [54].

Following prior studies analyzing the effect of innovation outputs on firm performance, both product and process innovation variables are one year lagged $[32,84]$.

\subsubsection{Moderating Variable}

In accordance with the theoretical arguments described in the previous section, family involvement in management is employed as a moderating variable. Family-managed firms usually pursue socioemotional goals over purely financial objectives [90,91], which could cause family managers to have a distinctive influence on different innovation activities with respect to their non-family counterparts [20,92]. Family involvement in management is defined as the active participation of the controlling family in the firm management for all family-owned businesses [54,83]. In line with recent studies [93], family involvement in both ownership and management was considered to build a dichotomous measure of family-managed firm. Thus, family-managed firm is operationalized as 1 if there is a family with majority ownership in the firm and at least one member of that family is actively involved in the firm management and 0 otherwise. 


\subsubsection{Control Variables}

Various control variables that are similar to those utilized in prior performance studies $[83,94]$ were adopted to ensure adequate model specification. First, the authors controlled for firm size, measured by total sales, due to larger firms may possess certain advantages such as greater capabilities, better skills, or market power, which may positively influence the obtaining of performance outcomes [92,95]. Second, the authors controlled for firm age, measured as the number of years since the firm's establishment, as younger firms are expected to outperform and exhibit more sustained economic growth than older firms [96]. Considering the skewness of both firm size and age, log-transformations of these control variables are implemented [97]. The authors also controlled for leverage, measured as debt to total assets ratio [49], and for customer bargaining power, measured as the percentage of sales obtained from the three largest customers [98]. Furthermore, the authors controlled for territorial specificities or context conditions [99] with dummy variables that represent seven Spanish territorial subdivisions (see Table 1 for a more detailed description of each territorial subdivision). Finally, because of the generated economic performance may vary among the specific subindustries in which businesses operate [50], a group of dummy variables representative of each activity sector is also included (see Table 1).

\subsection{Analytical Method}

The proposed hypotheses were checked via econometric analysis. Considering the longitudinal character of the sample, with most businesses observed around twelve years, a panel data methodology was used to analyze the effect of different innovation forms on sustainable economic performance and the moderating role of family involvement in management. The utilization of panel data makes it possible to control for unobservable heterogeneity at the firm level and to eliminate individual effects, thus reducing bias in the results. When applying panel data designs, it is common to use the Hausman test to distinguish between fixed-effects and random-effects models. Nevertheless, in this study, fixed-effect estimation is not appropriate given the time-invariant nature of both the moderating variable, i.e., family management, and certain control variables, such as territorial subdivisions and industries dummies [100]. Therefore, following prior research [101,102], it is more pertinent using random-effects models. According to the abovementioned specifications, different models based on the following equation are estimated: Sustainable economic performance $=\beta_{0}+\beta_{1}$ Intramural $R \mathcal{E} D_{t-3}$

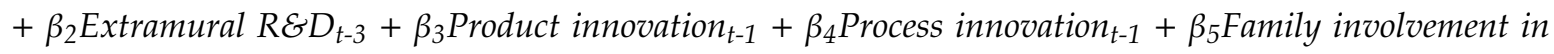
management $+\beta_{6}$ Intramural $R \mathcal{E} D_{t-3} x$ Family involvement in management $+\beta_{7}$ Extramural $R \mathcal{E} D_{t-3} x$ Family involvement in management $+\beta_{8}$ Product innovation $_{t-1} x$ Family involvement in management $+\beta_{9}$ Process innovation $_{t-1} x$ Family involvement in management $+\sum \beta_{j} x$ Controls $+\varepsilon$

\section{Data Analysis and Results}

Table 2 shows the means, the standard deviations and the correlations of the variables under study. The correlation matrix reveals that firm size and process innovation are positively and significantly related to sustainable economic performance, while leverage, intramural R\&D, and extramural $R \& D$ are negatively related to the dependent variable. The correlation matrix shows no indications of multicollinearity, as the correlation coefficients are all below the 0.8 threshold above which multicollinearity concerns could arise [103]. Additionally, variance inflation factors and condition indexes do not surpass 1.67 and 2.30, respectively, also confirming the absence of multicollinearity [103]. 
Table 2. Descriptive statistics, correlation matrix, and multicollinearity analysis.

\begin{tabular}{|c|c|c|c|c|c|c|c|c|c|c|c|c|}
\hline & $\mathbf{M}$ & SD & 1 & 2 & 3 & 4 & 5 & 6 & 7 & 8 & 9 & 10 \\
\hline 1. Sustainable economic performance & 0.101 & 0.119 & & & & & & & & & & \\
\hline 2. Firm size & 16.279 & 2.120 & $0.111^{* * *}$ & & & & & & & & & \\
\hline 3. Firm age & 3.116 & 0.729 & 0.003 & $0.317^{* * *}$ & & & & & & & & \\
\hline 4. Leverage & 0.493 & 0.231 & $-0.066^{* * *}$ & $0.094^{* * *}$ & $-0.082^{* * *}$ & & & & & & & \\
\hline 5. Customer bargaining power & 43.038 & 27.710 & -0.013 & $-0.036^{* * *}$ & $-0.063^{* * *}$ & $0.024^{* *}$ & & & & & & \\
\hline 6. Intramural $R \& D(t-3)$ & 0.006 & 0.019 & $-0.054^{* * *}$ & $0.165^{* * *}$ & $0.096^{* * *}$ & $0.033^{* *}$ & $-0.032^{* *}$ & & & & & \\
\hline 7. Extramural R\&D (t-3) & 0.003 & 0.017 & $-0.030^{* *}$ & $0.114^{* * *}$ & $0.075^{* * *}$ & $0.054^{* * *}$ & 0.020 & $0.290^{* * *}$ & & & & \\
\hline 8. Product innovation $(\mathrm{t}-1)$ & 0.207 & 0.405 & -0.003 & $0.254^{* * *}$ & $0.111^{* * *}$ & -0.005 & $-0.118^{* * *}$ & $0.234^{* * *}$ & $0.111^{* * *}$ & & & \\
\hline 9. Process innovation $(\mathrm{t}-1)$ & 0.370 & 0.483 & $0.087^{* * *}$ & $0.345^{* * *}$ & $0.114^{* * *}$ & 0.013 & -0.019 & $0.145^{* * *}$ & $0.088^{* * *}$ & $0.358^{* * *}$ & & \\
\hline 10. Family involvement in management & 0.499 & 0.500 & 0.012 & $-0.475^{* * *}$ & $-0.134^{* * *}$ & $-0.023^{*}$ & $-0.090^{* * *}$ & $-0.065^{* * *}$ & $-0.054^{* * *}$ & $-0.103^{* * *}$ & $-0.146^{* * *}$ & \\
\hline Variance inflation factors & & & & 1.67 & 1.13 & 1.04 & 1.04 & 1.16 & 1.10 & 1.25 & 1.28 & 1.33 \\
\hline Condition indexes & & & & 1.33 & 1.36 & 1.47 & 1.48 & 1.54 & 1.67 & 1.78 & 1.92 & 2.30 \\
\hline
\end{tabular}

Note: ${ }^{* * *} p<0.01{ }^{* *} p<0.05, * p<0.10$. Subindustries and territorial subdivisions dummies are not included for space reasons, but results are available from the authors. 
As previously commented, the hypotheses proposed in the research model were tested using random-effects regression analyses. Tables 3 and 4 report the regression results, considering sustainable economic performance as the dependent variable. Twelve different models (six in each table) were estimated to check the hypotheses, in order to explore various alternatives in which the innovation activities were entered either separately or together simultaneously. In all specifications, the innovation variables were lagged because both innovation inputs and innovation outputs influence future firm realization in subsequent years [94,104].

Table 3 allows checking the first four hypotheses. In this regard, Model 1 is the baseline model, which only includes the control variables. As expected, in line with prior research [105], firm size exerts a positive and significant effect on long-term performance $(\beta=0.021, p<0.01)$, whilst firm age and leverage exert a negative and significant effect on it $(\beta=-0.013, p<0.01, \beta=-0.077, p<0.01$, respectively). That is, firms larger in size, younger in age, and with lower levels of indebtedness, obtain higher sustainable economic performance. Moreover, customer bargaining power exerts a negative significant impact on the dependent variable $(\beta=-0.013, p<0.01)$. Then, Models $2,3,4$ and 5 present the obtained estimations when entering each one of the innovation forms (intramural R\&D, extramural R\&D, product innovation, and process innovation) individually. Consequently, Models 2-5 overlook the possibility that firms may perform different innovation activities simultaneously. Therefore, these models reveal the impact of each innovation activity individually considered on firms' long-term performance. Starting from Model 2, the results show that intramural R\&D intensity exerts a negative and significant impact on sustainable economic performance $(\beta=-0.438, p<0.01)$, which supports H1. In line with the above, Model 3 reflects the negative impact of extramural R\&D on firm performance $(\beta=-0.149, p<0.05)$, which also supports H2. Model 4 does not reveal a significant effect of product innovation on the dependent variable $(\beta=-0.005$, n.s.), and therefore, H3 is not supported. Moreover, Model 5 shows the positive and significant effect that process innovation exerts on sustainable economic performance $(\beta=0.007, p<0.05)$, supporting H4. Finally, Model 6 presents the regression results of a full-model specification in which all innovation variables were entered simultaneously. Thus, Model 6, by assuming that firms might develop various innovation practices at a time, provides more consistent estimators of the relationship between innovation forms and long-term performance, revealing the specific contribution of intramural and extramural $R \& D$, and of product and process innovation to sustainable economic performance. The results of Model 6 are consistent with those of previous models, revealing a negative impact of both intramural and extramural R\&D $(\beta=-0.422, p<0.01, \beta=-0.126, p<0.1$, respectively), and a positive effect of process innovation over long-term performance $(\beta=0.008, p<0.01)$. Again, the findings offer support for $\mathrm{H} 1, \mathrm{H} 2$, and $\mathrm{H} 4$.

Table 4 provides the required information to check H5. In this case, it is checked whether family management exert a moderating effect in the relationships between innovation inputs (intramural and extramural R\&D) and firm performance, and in the relationships between innovation outputs (product and process innovation) and firm performance. Model 7, in line with previous studies [106], highlights the positive and significant direct impact that family management exerts over firm performance $(\beta=0.007, p<0.1)$. Then, in Models $8-11$, the moderating effect of family management in the innovation forms and sustainable economic performance relationship is included. Models 8,9 and 10 do not reveal a significant moderating effect of family management $(\beta=0.218$, n.s., $\beta=0.209$, n.s., $\beta=0.130$, n.s.). On the contrary, Model 11 reveals a positive and significant impact of the moderating effect of family management on the process innovation and sustainable economic performance relationship $(\beta=0.012, p<0.05)$, which implies that family managers reinforce the positive relationship between process innovation and long-term performance. Finally, Model 12 corroborates the previous findings, by showing again a strengthening effect of family management on the relationship between process innovation and sustainable economic performance.

Therefore, it can be stated that H5 is partially supported. 
Table 3. Regression analysis results-direct effect of innovation forms on sustainable economic performance.

\begin{tabular}{|c|c|c|c|c|c|c|}
\hline & Model 1 & Model 2 & Model 3 & Model 4 & Model 5 & Model 6 \\
\hline \multicolumn{2}{|c|}{ Dependent Variable } & \multicolumn{5}{|c|}{ Sustainable economic performance } \\
\hline Main effects & & & & & & \\
\hline Intramural R\&D (t-3) & & $-0.438^{* * *}(0.090)$ & & & & $-0.422^{* * *}(0.091)$ \\
\hline Extramural R\&D (t-3) & & & $-0.149^{* *}(0.066)$ & & & $-0.126^{*}(0.066)$ \\
\hline Product innovation (t-1) & & & & $-0.005(0.004)$ & & $-0.006(0.004)$ \\
\hline Process innovation $(\mathrm{t}-1)$ & & & & & $0.007^{* *}(0.003)$ & $0.008^{* * *}(0.003)$ \\
\hline \multicolumn{7}{|l|}{ Controls } \\
\hline Firm size & $0.021^{* * *}(0.002)$ & $0.021^{* * *}(0.002)$ & $0.021^{* * *}(0.002)$ & $0.021^{* * *}(0.002)$ & $0.020^{* * *}(0.002)$ & $0.021^{* * *}(0.002)$ \\
\hline Firm age & $-0.013^{* * *}(0.005)$ & $-0.012^{* * *}(0.004)$ & $-0.013^{* * *}(0.005)$ & $-0.013^{* * *}(0.005)$ & $-0.013^{* * *}(0.005)$ & $-0.012^{* * *}(0.005)$ \\
\hline Leverage & $-0.077^{* * *}(0.008)$ & $-0.075^{* * *}(0.008)$ & $-0.077^{* * *}(0.008)$ & $-0.077^{* * *}(0.008)$ & $-0.077^{* * *}(0.008)$ & $-0.075^{* * *}(0.008)$ \\
\hline Customer bargaining power & $-0.013^{* * *}(0.005)$ & $-0.013^{* * *}(0.005)$ & $-0.001^{*}(0.001)$ & $-0.001^{*}(0.001)$ & $-0.001^{*}(0.001)$ & $-0.001^{*}(0.001)$ \\
\hline Territorial dummies & Included & Included & Included & Included & Included & Included \\
\hline Industry dummies & Included & Included & Included & Included & Included & Included \\
\hline Intercept & $-0.148^{* * *}(0.029)$ & $-0.155^{* * *}(0.029)$ & $-0.150^{* * *}(0.029)$ & $-0.150^{* * *}(0.029)$ & $-0.141^{* * *}(0.029)$ & $-0.150^{* * *}(0.029)$ \\
\hline Number of firms & 598 & 598 & 598 & 598 & 598 & 598 \\
\hline Number of observations & 5304 & 5304 & 5304 & 5304 & 5304 & 5304 \\
\hline Wald's $X^{2}$ & $248.57^{* * *}(10)$ & $273.13^{* * *}(11)$ & $253.91^{* * *}(11)$ & $250.71^{* * *}(11)$ & $254.40^{* * *}(11)$ & $286.12^{* * *}(14)$ \\
\hline $\mathrm{R}^{2}$ : within & 0.0690 & 0.0700 & 0.0692 & 0.0686 & 0.0690 & 0.0704 \\
\hline between & 0.0328 & 0.0368 & 0.0335 & 0.0334 & 0.0337 & 0.0392 \\
\hline overall & 0.0316 & 0.0357 & 0.0323 & 0.0322 & 0.0326 & 0.0381 \\
\hline
\end{tabular}

Note: Standard errors are in parentheses. ${ }^{* * *} p<0.01,{ }^{* *} p<0.05,{ }^{*} p<0.10$. 
Table 4. Regression analysis results-moderating effect of family involvement in management.

\begin{tabular}{|c|c|c|c|c|c|c|}
\hline & Model 7 & Model 8 & Model 9 & Model 10 & Model 11 & Model 12 \\
\hline Dependent Variable & & \multicolumn{5}{|c|}{ Sustainable economic performance } \\
\hline Main effects & & & & & & \\
\hline Intramural R\&D (t-3) & $-0.425^{* * *}(0.091)$ & $-0.546^{* * *}(0.129)$ & $-0.440^{* * *}(0.092)$ & $-0.430^{* * *}(0.091)$ & $-0.426^{* * *}(0.091)$ & $-0.521^{* * *}(0.130)$ \\
\hline Extramural R\&D (t-3) & $-0.134^{* *}(0.066)$ & $-0.127^{*}(0.066)$ & $-0.144^{* *}(0.069)$ & $-0.124^{*}(0.066)$ & $-0.123^{*}(0.066)$ & $-0.137^{* *}(0.069)$ \\
\hline Product innovation (t-1) & $-0.006(0.004)$ & $-0.006(0.004)$ & $-0.006(0.004)$ & $-0.007(0.004)$ & $-0.006(0.004)$ & $-0.008(0.005)$ \\
\hline Process innovation $(\mathrm{t}-1)$ & $0.008^{* * *}(0.003)$ & $0.008^{* * *}(0.003)$ & $0.008^{* * *}(0.003)$ & $0.008^{* * *}(0.003)$ & $0.002(0.004)$ & $0.003(0.004)$ \\
\hline Moderators & & & & & & \\
\hline & $0.007^{*}(0.004)$ & $0.006(0.004)$ & $0.007(0.004)$ & $0.004(0.004)$ & $0.003(0.004)$ & $0.001(0.005)$ \\
\hline Intramural $R \& D(t-3) \times$ Family involvement in management & & $0.218(0.164)$ & & & & $0.147(0.169)$ \\
\hline Extramural R\&D ( $\mathrm{t}-3)$ x Family involvement in management & & & $0.209(0.203)$ & & & $0.131(0.207)$ \\
\hline Product innovation $(\mathrm{t}-1) \mathrm{x}$ Family involvement in management & & & & $0.130(0.006)$ & & $0.008(0.007)$ \\
\hline $\begin{array}{c}\text { Process innovation }(\mathrm{t}-1) \mathrm{x} \text { Family involvement in management } \\
\text { Controls }\end{array}$ & & & & & $0.012^{* *}(0.005)$ & $0.011^{* *}(0.005)$ \\
\hline Firm size & $0.021^{* * *}(0.002)$ & $0.021^{* * *}(0.002)$ & $0.021^{* * *}(0.002)$ & $0.021^{* * *}(0.002)$ & $0.021^{* * *}(0.002)$ & $0.021^{* * *}(0.002)$ \\
\hline Firm age & $-0.012^{* * *}(0.005)$ & $-0.012^{* *}(0.005)$ & $-0.012^{* * *}(0.005)$ & $-0.012^{* * *}(0.005)$ & $-0.012^{* * *}(0.005)$ & $-0.012^{* * *}(0.005)$ \\
\hline Leverage & $-0.075^{* * *}(0.008)$ & $-0.075^{* * *}(0.008)$ & $-0.075^{* * *}(0.008)$ & $-0.075^{* * *}(0.008)$ & $-0.075^{* * *}(0.008)$ & $-0.075^{* * *}(0.008)$ \\
\hline Customer bargaining power & $-0.001 *(0.001)$ & $-0.001 *(0.001)$ & $-0.001 *(0.001)$ & $-0.001 *(0.001)$ & $-0.001 *(0.001)$ & $-0.001 *(0.001)$ \\
\hline Territorial dummies & Included & Included & Included & Included & Included & Included \\
\hline Industry dummies & Included & Included & Included & Included & Included & Included \\
\hline Intercept & $-0.163^{* * *}(0.030)$ & $-0.162^{* * *}(0.030)$ & $-0.162^{* * *}(0.030)$ & $-0.159^{* * *}(0.030)$ & $-0.160^{* * *}(0.030)$ & $-0.158(0.030)$ \\
\hline Number of firms & 598 & 598 & 598 & 598 & 598 & 598 \\
\hline Number of observations & 5,304 & 5,304 & 5,304 & 5,304 & 5,304 & 5,304 \\
\hline Wald's $X^{2}$ & $288.82^{* * *}(15)$ & $290.57^{* * *}(16)$ & $289.89^{* * *}(16)$ & $293.07^{* * *}(16)$ & $294.58^{* * *}(16)$ & $298.04^{* * *}(19)$ \\
\hline $\mathrm{R}^{2}$ : within & 0.0690 & 0.0697 & 0.0694 & 0.0701 & 0.0697 & 0.0712 \\
\hline between & 0.0424 & 0.0417 & 0.0418 & 0.0413 & 0.0424 & 0.0408 \\
\hline overall & 0.0406 & 0.0402 & 0.0402 & 0.0400 & 0.0408 & 0.0409 \\
\hline
\end{tabular}

Note: Standard errors are in parentheses. ${ }^{* * *} p<0.01,{ }^{* *} p<0.05,{ }^{*} p<0.10$ 
To show a more accurate view of the moderating effect of family management on the process innovation and sustainable economic performance relationship, Figure 2 shows the interaction effect by estimating the predicted values of sustainable economic performance under different conditions, that is, 0 and 1 values for process innovation and 0 and 1 values for family management, making the different effects visible [10]. This figure reveals that in the absence of process innovations, family-managed firms obtain a slightly higher predicted long-term performance than their non-family counterparts. Nevertheless, it is shown that when process innovations are undertaken, family-managed firms make the most of their idiosyncratic characteristics for innovation (e.g., social capital), achieving superior predicted levels of sustainable economic performance.

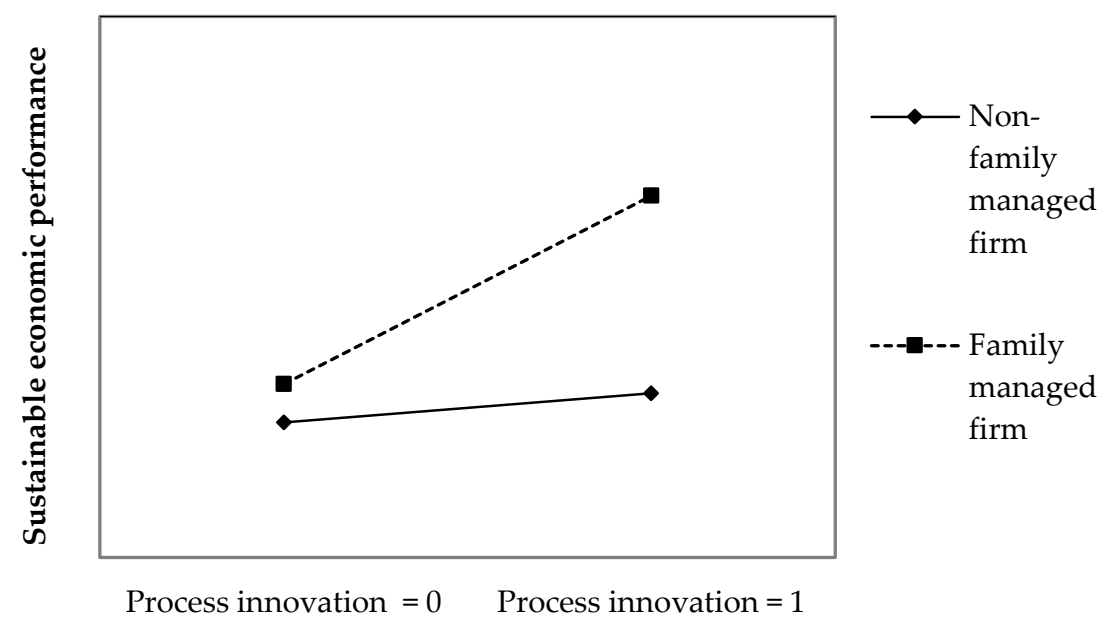

Figure 2. Moderating effect of family management on the process innovation and sustainable economic performance relationship.

\section{Discussion}

Examining how innovation influences sustainable performance, and namely, sustainable economic performance, has attracted the interest of numerous scholars in recent years $[3,12,17]$. This is due to the fact that more and more firms are facing the challenge of becoming sustainable businesses, and to this end, they find in innovation the driving force to boost sustained competitive advantages and achieve continuous growth of their outcomes over time [3,5]. However, there is not a general consensus with respect to the specific effect that innovation exerts on sustainable economic performance, because of the multifaceted and complex nature of both innovation and firm performance has led to mixed results $[9,27]$. Notwithstanding the significance of this theme, few studies to date have delved into how different innovation forms contribute to improving sustainable economic performance.

Thus, the aim of this study was to offer new insights on the relationship between innovation and sustainable economic performance, by analyzing the impact of four key innovation forms that firms may decide to undertake, individually or simultaneously, covering both innovation inputs and outputs. Namely, it was examined how intramural R\&D, extramural R\&D, product innovations, and process innovations contribute to the generation of firms' long-term performance. A further aim was to examine when and to what extent family involvement in management moderates the expected relationships between the aforementioned innovation forms and sustainable economic performance. To address these issues, a random-effects regression analysis was performed on a longitudinal sample of 598 Spanish private manufacturing firms.

The regression results confirm $\mathrm{H} 1$ and $\mathrm{H} 2$, as innovation inputs, that is, intramural and extramural $R \& D$, are found to exert a negative and significant impact on sustainable economic performance. In this vein, these findings are consistent with prior studies [31,84,107], which stated that although $R \& D$ investments are carried out with the purpose of obtaining innovation outputs and, therefore, enhancing firm performance, they imply substantial investments in sunk costs due to their expenditure 
nature $[108,109]$. Thus, the results support that $R \& D$ expenses, as an investment decision, reduce the firms' operating result, and thereby, the performance outcomes, because of the decrease in cash flow at the time of investment $[47,48,50]$.

Regarding the hypothesized positive effect of innovation outputs, that is, product and process innovations, on sustainable economic performance, the regression analyses find no support for $\mathrm{H} 3$, but confirm H4. On the one hand, the results show a non-significant effect of product innovation on sustainable economic performance. In this respect, previous studies reached similar results when relating product innovations to performance measures $[27,110]$, which reflects that higher profits generated by product innovations may be hampered, among other aspects, by constant changes in customers' needs or shortening of the product life cycles. On the other hand, the results reveal that process innovations exert a positive and significant impact on sustainable economic performance. This finding is also in line with prior research $[53,111]$ arguing that process innovations are crucial for the improvement of firms' internal efficiency, flexibility, and quality, leading to important savings in production costs and, thus, to increases in firms' operating results and long-term performance.

The findings regarding the effect that family involvement in management has on sustainable economic performance through its interaction with the analyzed innovation forms, show that family management intensifies the impact that process innovation exerts on long-term performance. The obtained results can be justified on the basis that family managers take full advantage of their idiosyncratic characteristics for innovation, such as the dissemination of tacit knowledge throughout the firm [77] or the establishment of fruitful relationships with several stakeholders [81]. Moreover, some authors [54] point out that family-managed firms also promote the development of efficient process innovations, and therefore, long-term performance, through their high commitment to friendly, honest, and close working relationships [90]. Furthermore, family managers make the most of process innovation-performance relationship, as a result of the unusual motivation, consolidated loyalties, and increased trust that they are able to promote between family managers and other employees [106,112]. Additionally, the utilization within a business of a distinctive family language [78], which improves the communication flow and joint decision-making, also impacts positively on innovation efficiency. Hence, H5d endorses the idea that family involvement in management provides an outstanding strengthening effect that enables better long-term performance outcomes when the firm is able to enhance its internal functioning through the implementation of process innovations. Finally, the results do not reveal any significant conclusions about the interaction effect between family involvement in management and the other three innovation forms ( $\mathrm{H} 5 \mathrm{a}, \mathrm{H} 5 \mathrm{~b}$, and $\mathrm{H} 5 \mathrm{c}$ ).

\section{Challenging Issues and Future Research Orientations}

This article makes important contributions to the literature. An in-depth analysis of sustainable economic performance is conducted. Although the concept of sustainable performance has received increased attention in recent years [5,17], its examination from an economic perspective remains a key challenge [4]. Moreover, to the best of the authors' knowledge, there are few studies that have examined this phenomenon in a private firm context, usually due to the difficulties in accessing reliable economic data of these firms $[113,114]$, which would also explain the reduced number of panel data studies on this topic [107]. This study also provides a more nuanced picture of the multifaceted nature of innovation and its effect on firm performance, examining individually and simultaneously, how four different innovation forms, i.e., intramural R\&D, extramural R\&D, product innovation and process innovation, have disparate effects on sustainable economic performance. Hence, this article contributes to theory testing [115] by analyzing a previously unexplored link in a private firm context, that is, the relationship between innovation forms and sustainable economic performance. Furthermore, this study introduces a potential moderator, namely, family involvement in management, to outline when and under what circumstances the aforementioned links are demonstrated.

Despite the interesting obtained results, this study presents some limitations, leading to interesting avenues for future research. It is examined how different innovation forms impact on sustainable 
economic performance, measured through a specific performance indicator, that is, ROA. Nevertheless, as abovementioned, performance is a multidimensional construct, difficult to synthesize into a sole indicator [9]. Hence, future studies should investigate the influence of different innovation forms on diverse performance indicators such as return on investment, gross margin, and return on equity, among others. Furthermore, the ESEE does not provide information related to the social and environmental aspects of firm performance. Therefore, future efforts should be made to investigate how the examined innovation forms may impact on social and environmentally sustainable performance. Another limitation is related to the measurement of innovation outputs (products and process innovations), as dichotomous variables are used, which may lead to a lack of information on the development of new products and processes [89]. Therefore, future research should strive in measuring both product and process innovations on a continuous way to obtain more accurate results of their effect on firms' long-term performance. Moreover, this study focuses on the indirect effect of family involvement in management. Thus, future research might consider other family dimensions, such as family involvement in ownership and in governance [92], to assess how they interact with different innovation forms to achieve long-term performance. Besides, a further limitation involves the utilization of a dichotomous distinction among family and non-family-managed firms, which does not reflect the heterogeneity that characterizes the former $[107,116]$. Hence, future studies should analyze how family firm heterogeneity in goals or values within firm management may influence innovation in the obtaining of sustainable economic performance.

Finally, although the present study covers a specific economic sector, i.e., manufacturing, which is especially well suited for the research objectives, it could limit the possibility of generalizing the empirical results. Therefore, future research should consider other activity industries to test the suggested hypotheses. Moreover, studies examining the themes that have been addressed here, but in other regions or countries, would further this area of expertise.

The obtained findings also have notable practical implications. A better comprehension of how innovation improves firms' sustainable economic performance is essential for academics, professionals, and consultants. Similarly, a more nuanced understanding of the influence that family involvement in management has on the abovementioned relationship is of utmost importance, as family firms represent the backbone of the world economy [117]. Regarding the pernicious effects that innovation inputs (intramural and extramural R\&D expenses) have on sustainable economic performance, they can be combated by reducing R\&D expenditure to a certain level and maximizing the outcomes of such expenditure through the implementation of an innovative business culture that fosters innovation efficiency [118]. In other words, through more efficient and appropriate management of innovation resources on the part of firm managers, it would be possible to get more positive innovation outcomes with a lower level of $R \& D$ expenditure. On the other hand, whether family involvement in management increases the positive effect that process innovation exerts on sustainable economic performance, these linkages should be strengthened. This favorable effect may be increased through greater dissemination of tacit knowledge within the firm as well as the establishment of close and trusting relationships between family members. Moreover, governments and policymakers, in an attempt to improve the long-term performance of family-managed firms, should develop certain policies to incentive the development of more efficient process innovations, such as public programs and subsidies that support internal innovations in production processes or delivery methods.

\section{Conclusions}

This study reveals that intramural $R \& D$, extramural $R \& D$, and process innovation, have an impact on the sustainable economic performance of Spanish private manufacturing firms. Moreover, the findings reveal that family involvement in management acts as a moderator of the relationship between process innovation and long-term performance, leading to higher sustainable economic performance. Although this research extends the theoretical and empirical contributions of the 
recent literature [12,19], further research is required on the relationships between alternative innovation forms, sustainable economic performance and the role of family involvement in management.

Author Contributions: This article was a collaborative effort of R.M.-A., M.J.M.-R., and A.A.R.-R.; R.M.-A., M.J.M.-R., and A.A.R.-R. contributed equally to this work.

Funding: This research received external funding from a Research Project of the Universidad de Almería, Spain.

Acknowledgments: Rubén Martínez-Alonso acknowledges the funding received by the Spanish Ministry of Science, Innovation and Universities in the form of a Research Grant to develop his PhD (FPU-17/01359), and thereby, this paper.

Conflicts of Interest: The authors declare no conflict of interest.

\section{References}

1. López-Pérez, M.E.; Melero-Polo, I.; Vázquez-Carrasco, R.; Cambra-Fierro, J. Sustainability and business outcomes in the context of SMEs: Comparing family firms vs. non-family firms. Sustainability 2018, 10, 4080. [CrossRef]

2. Hahn, T.; Scheermesser, M. Approaches to corporate sustainability among German companies. Corp. Soc. Responsib. Environ. Manag. 2006, 13, 150-165. [CrossRef]

3. Kuhl, M.R.; da Cunha, J.C.; Maçaneiro, M.B.; da Cunha, S.K. Relationship between innovation and sustainable performance. Braz. Bus. Rev. 2016, 13, 1-25. [CrossRef]

4. Székely, F.; Knirsch, M. Responsible leadership and corporate social responsibility: Metrics for sustainable performance. Eur. Manag. J. 2005, 23, 628-647. [CrossRef]

5. Marhraoui, M.A.; Manouar, A. IT Innovation and Firm's Sustainable Performance: The Intermediary Role of Organizational Agility_An Empirical Study. Int. J. Inf. Eng. Electron. Bus. 2018, 10, 1-7. [CrossRef]

6. Uysal, F. An Integrated Model for Sustainable Performance Measurement in Supply Chain. Procedia-Soc. Behav. Sci. 2012, 62, 689-694. [CrossRef]

7. Gary, H.; Välikangas, L. The quest for resilience. Harv. Bus. Rev. 2003, 81, 52-63.

8. Williams, N.; Vorley, T. Economic resilience and entrepreneurship: Lessons from the Sheffield City Region. Entrep. Reg. Dev. 2014, 26, 257-281. [CrossRef]

9. Casillas, J.C.; Moreno, A.M.; Barbero, J.L. A Configurational Approach of the Relationship Between Entrepreneurial Orientation and Growth of Family Firms. Fam. Bus. Rev. 2010, 23, 27-44. [CrossRef]

10. Martínez-Alonso, R.; Martínez-Romero, M.J.; Rojo-Ramírez, A.A. The impact of technological innovation efficiency on firm growth: the moderating role of family involvement in management. Eur. J. Innov. Manag. 2019. [CrossRef]

11. Wiklund, J.; Shepherd, D. Entrepreneurial orientation and small business performance: A configurational approach. J. Bus. Ventur. 2005, 20, 71-91. [CrossRef]

12. Asad, M. Impact of innovation practices on sustainable performance SMEs. Her. Namsca 2018, 3, 537-546.

13. Gomes, C.M.; Kruglianskas, I.; Scherer, F.L. Innovation management for sustainable development practices in the internalization context. J. Technol. Manag. Innov. 2011, 6, 110-127. [CrossRef]

14. Blundell, R.; Griffith, R.; Van Reenen, J. Market share, market value and innovation in a panel of British manufacturing firms. Rev. Econ. Stud. 1999, 66, 529-554. [CrossRef]

15. Damanpour, F.; Szabat, K.A.; Evan, W.M. The relationship between types of innovation and organizational performance. J. Manag. Stud. 1989, 26, 587-602. [CrossRef]

16. Rosenbusch, N.; Brinckmann, J.; Bausch, A. Is innovation always beneficial? A meta-analysis of the relationship between innovation and performance in SMEs. J. Bus. Ventur. 2011, 26, 441-457. [CrossRef]

17. Cheah, S.; Ho, Y.P.; Li, S. Business model innovation for sustainable performance in retail and hospitality industries. Sustainability 2018, 10, 3952. [CrossRef]

18. Atalay, M.; Anafarta, N.; Sarvan, F. The Relationship between Innovation and Firm Performance: An Empirical Evidence from Turkish Automotive Supplier Industry. Procedia-Soc. Behav. Sci. 2013, 75, 226-235. [CrossRef]

19. Diéguez-Soto, J.; Manzaneque, M.; Rojo-Ramírez, A.A. Technological Innovation Inputs, Outputs and Performance: the Moderating Role of Family Involvement in Management. Fam. Bus. Rev. 2016, 29, 327-346. [CrossRef] 
20. Martínez-Alonso, R.; Martínez-Romero, M.J.; Rojo-Ramírez, A.A. Technological innovation and Socioemotional wealth in family firm research: literature review and proposal of a conceptual framework. Manag. Res. J. Iberoam. Acad. Manag. 2018, 16, 270-301. [CrossRef]

21. Martínez-Ros, E.; Labeaga, J.M. Product and process innovation: Persistence and complementarities. Eur. Manag. Rev. 2009, 6, 64-75. [CrossRef]

22. Lee, N.; Lee, J. R \& D Intensity and Dividend Policy: Evidence from South Korea's Biotech Firms. Sustainability 2019, 11, 4837. [CrossRef]

23. Coad, A.; Rao, R. Innovation and firm growth in high-tech sectors: A quantile regression approach. Res. Policy 2008, 37, 633-648. [CrossRef]

24. Eiriz, V.; Faria, A.; Barbosa, N. Firm growth and innovation: Towards a typology of innovation strategy. Innov. Manag. Policy Pract. 2013, 15, 97-111. [CrossRef]

25. Crossan, M.M.; Apaydin, M. A Multi-Dimensional Framework of Organizational Innovation: A Systematic Review of the Literature. J. Manag. Stud. 2010, 47, 1154-1191. [CrossRef]

26. Tavassoli, S. The role of product innovation on export behavior of firms: Is it innovation input or innovation output that matters? Eur. J. Innov. Manag. 2018, 21, 294-314. [CrossRef]

27. Bianchini, S.; Pellegrino, G.; Tamagni, F. Innovation complementarities and firm growth. Ind. Corp. Chang. 2018, 27, 657-676. [CrossRef]

28. Diéguez-Soto, J.; Martínez-Romero, M.J. Family Involvement in Management and Product Innovation: The Mediating Role of R\&D Strategies. Sustainability 2019, 11, 2162. [CrossRef]

29. Hervas-Oliver, J.L.; Sempere-Ripoll, F.; Boronat-Moll, C. Process innovation strategy in SMEs, organizational innovation and performance: A misleading debate? Small Bus. Econ. 2014, 43, 873-886. [CrossRef]

30. Ettlie, J.E. R\&D and Global Manufacturing Performance. Manag. Sci. 1998, 44, 1-11. [CrossRef]

31. Pantagakis, E.; Terzakis, D.; Arvanitis, S. R\&D Investments and Firm Performance: An E.U. Ssrn 2012. [CrossRef]

32. Artz, K.W.; Norman, P.M.; Hatfield, D.E.; Cardinal, L.B. A longitudinal study of the impact of R\&D, patents, and product innovation on firm performance. J. Prod. Innov. Manag. 2010, 27, 725-740. [CrossRef]

33. Diéguez-Soto, J.; Manzaneque, M.; González-García, V.; Galache-Laza, T. A study of the moderating influence of R\&D intensity on the family management-firm performance relationship: Evidence from Spanish private manufacturing firms. Brq Bus. Res. Q. 2019, 22, 105-118. [CrossRef]

34. OECD. Oslo Manual. Guidelines for Collecting and Interpreting Innovation Data; OECD: Paris, France, 2005.

35. Grimpe, C.; Kaiser, U. Balancing internal and external knowledge acquisition: The gains and pains from R \& D outsourcing. J. Manag. Stud. 2010, 47, 1483-1509. [CrossRef]

36. Cohen, W.M.; Levinthal, D.A. Absorptive Capacity: A New Perspective on Learning and Innovation. Adm. Sci. Q. 1990, 35, 128-152. [CrossRef]

37. Cruz-Cázares, C.; Bayona-Sáez, C.; García-Marco, T. R\&D Strategies and firm innovative performance: A panel data analysis. Int. J. Innov. Manag. 2010, 14, 1013-1045. [CrossRef]

38. Griliches, Z. Issues in Assessing the Contribution of Research and Development to Productivity Growth. Bell J. Econ. 1979, 10, 92-116. [CrossRef]

39. Bayona-Sáez, C.; Cruz-Cázares, C.; García-Marco, T. Public R\&D funding: Does the source determine the strategy? Technol. Anal. Strateg. Manag. 2013, 25, 235-248. [CrossRef]

40. Perrons, R.K.; Platts, K. The role of clockspeed in outsourcing decisions for new technologies: Insights from the prisoner's dilemma. Ind. Manag. Data Syst. 2004, 104, 624-632. [CrossRef]

41. Berchicci, L. Towards an open R\&D system: Internal R\&D investment, external knowledge acquisition and innovative performance. Res. Policy 2013, 42, 117-127. [CrossRef]

42. DeSarbo, W.S.; Benedetto, C.A.; Song, M.; Sinha, I. Revisiting the miles and snow strategic framework: Uncovering interrelationships between strategic types, capabilities, environmental uncertainty, and firm performance. Strateg. Manag. J. 2005, 26, 47-74. [CrossRef]

43. West, A. Estrategia de Innovación; Clásicos COTEC: Madrid, Spain, 2002.

44. Narula, R. Choosing Between Internal and Non-internal R\&D Activities: Some Technological and Economic Factors. Technol. Anal. Strateg. Manag. 2001, 13, 365-387. [CrossRef] 
45. Ehie, I.C.; Olibe, K. The effect of R\&D investment on firm value: An examination of US manufacturing and service industries. Int. J. Prod. Econ. 2010, 128, 127-135. [CrossRef]

46. Ganotakis, P.; Love, J.H. The innovation value chain in new technology-based firms: Evidence from the UK. J. Prod. Innov. Manag. 2012, 29, 839-860. [CrossRef]

47. Penman, S.H. Handling Valuation Models. J. Appl. Corp. Financ. 2006, 18, 48-55. [CrossRef]

48. Petersen, C.; Plenborg, T. The implementation and application of firm valuation models. J. Appl. Bus. Res. 2009, 25, 1-12. [CrossRef]

49. Block, J.H. R\&D investments in family and founder firms: An agency perspective. J. Bus. Ventur. 2012, 27, 248-265. [CrossRef]

50. Martínez-Romero, M.J.; Rojo-Ramírez, A.A.; Casado-Belmonte, M.P. Value creation in privately held family businesses: The moderating role of socioemotional wealth. Can. J. Adm. Sci. 2019. [CrossRef]

51. Damanpour, F.; Gopalakrishnan, S. The Dynamics of the Adoption of Product and Process Innovations in Organizations. J. Manag. Stud. 2001, 38, 45-65. [CrossRef]

52. Kallmuenzer, A.; Scholl-Grissemann, U. Disentangling antecedents and performance effects of family SME innovation: A knowledge-based perspective. Int. Entrep. Manag. J. 2017, 13, 1117-1138. [CrossRef]

53. Ruiz-Palomo, D.; Diéguez-Soto, J.; Duréndez, A.; Santos, J.A.C. Family Management and Firm Performance in Family SMEs: The Mediating Roles of Management Control Systems and Technological Innovation. Sustainability 2019, 11, 3805. [CrossRef]

54. Diéguez-Soto, J.; Garrido-Moreno, A.; Manzaneque, M. Unravelling the link between process innovation inputs and outputs: The moderating role of family management. J. Fam. Bus. Strategy 2018, 9, 114-127. [CrossRef]

55. Grønhaug, K.; Kaufmann, G. Innovation: A Cross-Disciplinary Perspective; Norwegian University Press: Oslo, Norway, 1988.

56. Lodh, S.; Nandy, M.; Chen, J. Innovation and family ownership: Empirical evidence from India. Corp. Gov. Int. Rev. 2014, 22, 4-23. [CrossRef]

57. O'Regan, N.; Ghobadian, A.; Gallear, D. In search of the drivers of high growth in manufacturing SMEs. Technovation 2006, 26, 30-41. [CrossRef]

58. Allocca, M.A.; Kessler, E.H. Innovation Speed in Small and Medium-Sized Enterprises. Creat. Innov. Manag. 2006, 15, 279-295. [CrossRef]

59. Gudmundson, D.; Tower, B.C.; Hartman, A.E. Innovation in Small Businesses: Culture and Ownership Structure Do Matter. J. Dev. Entrep. 2003, 8, 1-17.

60. Chen, S.; Xu, K.; Nguyen, L.T.; Yu, G. TMT's attention towards financial goals and innovation investment: Evidence from China. Sustainability 2018, 10, 4236. [CrossRef]

61. Gunday, G.; Ulusoy, G.; Kilic, K.; Alpkan, L. Effects of innovation types on firm performance. Int. J. Prod. Econ. 2011, 133, 662-676. [CrossRef]

62. Uhlaner, L.M.; van Stel, A.; Duplat, V.; Zhou, H. Disentangling the effects of organizational capabilities, innovation and firm size on SME sales growth. Small Bus. Econ. 2013, 41, 581-607. [CrossRef]

63. Sánchez-Sellero, P.; Sánchez-Sellero, M.C.; Sánchez-Sellero, F.J.; Cruz-González, M.M. Effects of Innovation on Technical Progress in Spanish Manufacturing Firms. Sci. Technol. Soc. 2015, 20, 44-59. [CrossRef]

64. Smolny, W. Innovations, Prices and Employment: A Theoretical Model and an Empirical Application for West German Manufacturing Firms. J. Ind. Econ. 1998, 46, 359-381. [CrossRef]

65. La Porta, R.; Lopez-De-Silanes, F.; Shleifer, A. Corporate Ownership Around the World. J. Financ. 1999, 54, 471-517. [CrossRef]

66. Zellweger, T.M. Managing the Family Business: Theory and Practice; Edward Elgar Publishing: Cheltenham, UK, 2017.

67. Gómez-Mejía, L.R.; Cruz, C.; Berrone, P.; De Castro, J. The Bind that Ties: Socioemotional Wealth Preservation in Family Firms. Acad. Manag. Ann. 2011, 5, 653-707. [CrossRef]

68. Martin, G.; Gómez-Mejía, L.R. The relationship between socioemotional and financial wealth: Re-visiting family firm decision making. Manag. Res. J. Iberoam. Acad. Manag. 2016, 14, 234-243. [CrossRef]

69. Le Breton-Miller, I.; Miller, D.; Lester, R.H. Stewardship or agency? A social embeddedness reconciliation of conduct and performance in public family businesses. Organ. Sci. 2011, 22, 704-721. [CrossRef] 
70. Berent-Braun, M.M.; Flören, R.H.; Ouden, M.M.C.M. Den. Being Able and Willing to Innovate: A Study of Family Firm Identity and New Product Output among Dutch Private Businesses. Int. Rev. Entrep. 2018, 16, 183-215.

71. Chrisman, J.J.; Chua, J.H.; Sharma, P. Trends and Directions in the Development of a Strategic Management Theory of the Family Firm. Entrep. Theory Pract. 2005, 29, 555-575. [CrossRef]

72. Calabrò, A.; Vecchiarini, M.; Gast, J.; Campopiano, G.; De Massis, A.; Kraus, S. Innovation in Family Firms: A Systematic Literature Review and Guidance for Future Research. Int. J. Manag. Rev. 2019, 21, 317-355. [CrossRef]

73. Demsetz, H.; Lehn, K. The Structure of Corporate Ownership: Causes and Consequences. J. Political Econ. 1985, 93, 1155-1177. [CrossRef]

74. Revilla, A.J.; Perez-Luno, A.; Nieto, M.J. Does Family Involvement in Management Reduce the Risk of Business Failure? The Moderating Role of Entrepreneurial Orientation. Fam. Bus. Rev. 2016, 29, 365-379. [CrossRef]

75. Martínez-Romero, M.J.; Martínez-Alonso, R.; Casado-Belmonte, M.P.; Rojo-Ramírez, A.A. The Moderating Effect of Family Management on R\&D Productivity in Privately Held Firms. In Handbook of Research on Entrepreneurship, Innovation, and Internationalization; Teixeira, N.M., Costa, T.G., Lisboa, I.M., Eds.; IGI Global: Hershey, PA, USA, 2019; pp. 309-338. [CrossRef]

76. Brigham, K.H.; Lumpkin, G.T.; Tyge Payne, G.; Zachary, M.A. Researching Long-Term Orientation: A Validation Study and Recommendations for Future Research. Fam. Bus. Rev. 2014, 27, 72-88. [CrossRef]

77. Patel, P.C.; Fiet, J.O. Knowledge combination and the potential advantages of family firms in searching for opportunities. Entrep. Theory Pract. 2011, 35, 1179-1197. [CrossRef]

78. Sánchez-Famoso, V.; Maseda, A.; Iturralde, T. Family involvement in top management team: Impact on relationships between internal social capital and innovation. J. Manag. Organ. 2017, 23, 136-162. [CrossRef]

79. Nieto, M.J.; Santamaria, L.; Fernandez, Z. Understanding the Innovation Behavior of Family Firms. J. Small Bus. Manag. 2015, 53, 382-399. [CrossRef]

80. Cabrera-Suárez, K.; De Saá-Pérez, P.; García-Almeida, D. The Succession Process from a Resource- and Knowledge-Based View of the Family Firm. Fam. Bus. Rev. 2001, 14, 37-46. [CrossRef]

81. Miller, D.; Le-Breton-Miller, I. Managing for the Long Run: Lessons in Competitive Advantage from Great Family Businesses; Harvard Business School Press: Cambridge, UK, 2005.

82. Carney, M. Corporate Governance and Competitive Advantage in Family-Controlled Firms. Entrep. Theory Pract. 2005, 29, 249-265. [CrossRef]

83. Kotlar, J.; De Massis, A.; Frattini, F.; Bianchi, M.; Fang, H. Technology acquisition in family and nonfamily firms. J. Prod. Innov. Manag. 2013, 30, 1073-1088. [CrossRef]

84. Cruz-Cázares, C.; Bayona-Sáez, C.; García-Marco, T. You can't manage right what you can't measure well: Technological innovation efficiency. Res. Policy 2013, 42, 1239-1250. [CrossRef]

85. Cho, H.J.; Pucik, V. Relationship between innovativeness, quality, growth, profitability, and market value. Strateg. Manag. J. 2005, 26, 555-575. [CrossRef]

86. Gomez, J.; Vargas, P. The effect of financial constraints, absorptive capacity and complementarities on the adoption of multiple process technologies. Res. Policy 2009, 38, 106-119. [CrossRef]

87. Van de Vrande, V.; De Jong, J.P.J.; Vanhaverbeke, W.; De Rochemont, M. Open innovation in SMEs: Trends, motives and management challenges. Technovation 2009, 29, 423-437. [CrossRef]

88. Guan, J.; Zuo, K. A cross-country comparison of innovation efficiency. Scientometrics 2014, 100, 541-575. [CrossRef]

89. Antolín-López, R.; Céspedes-Lorente, J.; García-De-Frutos, N.; Martínez-Del-Río, J.; Pérez-Valls, M. Fostering product innovation: Differences between new ventures and established firms. Technovation 2015, 41-42, 25-37. [CrossRef]

90. Gómez-Mejía, L.R.; Haynes, K.T.; Núñez-Nickel, M.; Jacobson, K.J.L.; Moyano-Fuentes, J. Socioemotional Wealth and Business Risks in Family-controlled Firms: Evidence from Spanish Olive Oil Mills. Adm. Sci. Q. 2007, 52, 106-137. [CrossRef]

91. Rojo-Ramírez, A.A.; Martínez-Romero, M.J. Required and obtained equity returns in privately held businesses: The impact of family nature-evidence before and after the global economic crisis. Rev. Manag. Sci. 2018, 12, 771-801. [CrossRef] 
92. Matzler, K.; Veider, V.; Hautz, J.; Stadler, C. The Impact of Family Ownership, Management, and Governance on Innovation. J. Prod. Innov. Manag. 2015, 32, 319-333. [CrossRef]

93. Cruz, C.; Nordqvist, M. Entrepreneurial orientation in family firms: a generational perspective. Small Bus. Econ. 2012, 38, 33-49. [CrossRef]

94. Manzaneque, M.; Rojo-Ramírez, A.A.; Diéguez-Soto, J.; Martínez-Romero, M.J. How negative aspiration performance gaps affect innovation efficiency. Small Bus. Econ. 2018. [CrossRef]

95. Coluccia, D.; Dabić, M.; Del Giudice, M.; Fontana, S.; Solimene, S. R\&D innovation indicator and its effects on the market. An empirical assessment from a financial perspective. J. Bus. Res. 2019. [CrossRef]

96. Tsao, S.-M.; Lien, W.-H. Family Management and Internationalization: The Impact on Firm Performance and Innovation. Manag. Int. Rev. 2011, 53, 189-213. [CrossRef]

97. Arzubiaga, U.; Kotlar, J.; De Massis, A.; Maseda, A.; Iturralde, T. Entrepreneurial orientation and innovation in family SMEs: Unveiling the (actual) impact of the Board of Directors. J. Bus. Ventur. 2018, 33, 455-469. [CrossRef]

98. Kotlar, J.; Fang, H.; De Massis, A.; Frattini, F. Profitability Goals, Control Goals, and the R\&D Investment Decisions of Family and Nonfamily Firms. J. Prod. Innov. Manag. 2014, 31, 1128-1145. [CrossRef]

99. Camagni, R.; Capello, R. Regional Innovation Patters and the EU Regional Policy Reform: Toward Smart Innovation Policies. Growth Chang. 2013, 44, 355-389. [CrossRef]

100. Cameron, A.C.; Trivedi, P.K. Microeconometrics Using Stata; Stata Press: College Station, TX, USA, 2010.

101. Diéguez-Soto, J.; López-Delgado, P. Does Family and Lone Founder Involvement Lead to Similar Indebtedness? J. Small Bus. Manag. 2019, 57, 1531-1558. [CrossRef]

102. González, M.; Guzmán, A.; Pombo, C.; Trujillo, M.A. Family firms and debt: Risk aversion versus risk of losing control. J. Bus. Res. 2013, 66, 2308-2320. [CrossRef]

103. Hair, J.F.; Anderson, R.E.; Tatham, R.L.; Black, W.C. Analisis Multivariante; Prentice Hall: Madrid, Spain, 1999.

104. Liang, Q.; Li, X.; Yang, X.; Lin, D.; Zheng, D. How does family involvement affect innovation in China? Asia Pac. J. Manag. 2013, 30, 677-695. [CrossRef]

105. Casillas, J.C.; Moreno, A.M. The relationship between entrepreneurial orientation and growth: The moderating role of family involvement. Entrep. Reg. Dev. 2010, 22, 265-291. [CrossRef]

106. Gallucci, C.; Santulli, R.; Calabrò, A. Does family involvement foster or hinder firm performance? The missing role of family-based branding strategies. J. Fam. Bus. Strategy 2015, 6, 155-165. [CrossRef]

107. Martínez-Romero, M.J.; Martínez-Alonso, R.; Rojo-Ramírez, A.A.; Diéguez-Soto, J. Understanding Family Firm Profitability Heterogeneity. Differences Within Family Managed Firms and the Interaction Effect of Innovative Effort. In Competitiveness, Organizational Management, and Governance in Family Firms; Camison, C., González, T., Eds.; IGI Global: Hershey, PA, USA, 2020; pp. 305-329. [CrossRef]

108. Chrisman, J.J.; Patel, P.C. Variations in R\&D investments of family and nonfamily firms: Behavioral agency and myopic loss aversion perspectives. Acad. Manag. J. 2012, 55, 976-997. [CrossRef]

109. Kor, Y. Direct and interaction effects of top management team and board compositions on R\&D investment strategy. Strateg. Manag. J. 2006, 27, 1081-1099. [CrossRef]

110. Triguero, A.; Córcoles, D.; Cuerva, M.C. Persistence of innovation and firm's growth: Evidence from a panel of SME and large Spanish manufacturing firms. Small Bus. Econ. 2014, 43, 787-804. [CrossRef]

111. Klomp, L.; Leeuwen, G. Linking Innovation and Firm Performance: A New Approach. Int. J. Econ. Bus. 2001, 8, 343-364. [CrossRef]

112. Tagiuri, R.; Davis, J. Bivalent Attributes of the Family Firm. Fam. Bus. Rev. 1996, 9, 199-208. [CrossRef]

113. Carney, M.; Van Essen, M.; Gedajlovic, E.R.; Heugens, P.P.M.A.R. What do we know about private family firms? A meta-analytical review. Entrep. Theory Pract. 2015, 39, 513-544. [CrossRef]

114. George, G. Slack resources and the performance of privately held firms. Acad. Manag. J. 2005, 48, 661-676. [CrossRef]

115. Colquitt, J.A.; Zapata-Phelan, C.P. Trends in Theory Building and Theory Testing: A Five-Decade Study of the Academy of Management Journal. Acad. Manag. Rev. 2007, 50, 1281-1303. [CrossRef]

116. Chua, J.H.; Chrisman, J.J.; Steier, L.P.; Rau, S.B. Sources of Heterogeneity in Family Firms: An Introduction. Entrep. Theory Pract. 2012, 36, 1103-1113. [CrossRef] 
117. Family Firm Institute. Global Data Points. 2018. Available online: https://my.ffi.org/page/globaldatapoints (accessed on 5 August 2019).

118. Martínez-Romero, M.J.; Martínez-Alonso, R.; Casado-Belmonte, M.P.; Diéguez-Soto, J. Family management and firm performance-The interaction effect of technological innovation efficiency. In Intrapreneurship and Sustainable Human Capital: Digital Transformation through Dynamic Competences; Springer: Berlin, Germany, 2019. 